\title{
Acute intoxications in two university hospitals in Burkina Faso
}

\author{
*Ouédraogo M, Ouédraogo M, Yéré S, Traoré S, Guissou IP
}

UFR/ Sciences de la Santé, Université de Ouagadougou, 03 BP 7021 Ouagadougou, Burkina Faso.

\begin{abstract}
Introduction: Acute intoxications become more and more a serious problem in developing countries. However, epidemiologic data are very scarce in these countries.

Objective: To describe the characteristics of acute intoxications in two University Hospitals of Ouagadougou (Burkina Faso).

Methods: All cases admitted to the emergency services of the two sole University Hospitals of Ouagadougou from July 1 , 2006 to June 30, 2007, were included. We analysed the medical records for demographical and etiological characteristics of the acute poisoned-patients.

Results: Acute poisoned-patients (436) represented 1.9\% of the patients admitted to these services. The majority of acute poisoned-patients were pre-school children followed by young adults. Accidental intoxications (70.8\%) were more common than intentional (28.9) and suicidal attempts (0.3\%). Among poisoned-patients, female patients represented a great majority. Pharmaceuticals were the most common cause of acute intoxication, followed by chemicals, animals' toxins, food, alcohol and addictive drugs.

Conclusion: Our study revealed that pharmaceuticals were the most common cause of acute intoxications. The great majority of poisoned-patients were young. Female patients were the major poisoned-patients. Most admissions in the emergency services due to acute intoxications resulted from accidental poisoning.

Key words: Acute intoxication; Characteristics; Retrospective study; Burkina Faso.

African Health Sciences 2012; (4): 483 - 486 http://dx.doi.org/10.4314/ahs.v12i4.14
\end{abstract}

\section{Introduction}

Acute intoxications are clinical distresses that occur soon after a brief exposure to toxic substances. They can be the result of either a single exposure or multiple exposures occurring within a short time (generally less than 24 hours). Acute intoxications become more and more a serious problem in developing countries. Their frequency become higher and higher, and there are many difficulties to take care of the victims. ${ }^{1} \mathrm{~A}$ few epidemiological studies of acute intoxications among children in countries of Sub-Saharan Africa have been published. ${ }^{2-6}$ Concerning the epidemiology of global acute intoxications, data are very scarce in these countries. However, knowledge about characteristics of acute intoxications could contribute to their effective prevention and management.

In the best of our knowledge, no studies have been published on epidemiology of acute intoxications in Burkina Faso. Besides, there is no

${ }^{*}$ Corresponding author:
Moustapha Ouédraogo
UFR/ Sciences de la Santé
Université de Ouagadougou
03 BP 7021 Ouagadougou
Burkina Faso
E-mail : mustapha ouedraogo@yahoo.fr

African Health Sciences Vol 12 Issue 4 December 2012 centre for poison control in Burkina Faso to gather information about acute intoxications.

So, the aim of the current study was to describe the characteristics of acute intoxications in two University Hospitals of Burkina Faso.

\section{Methods}

The study was carried out in the two University Hospitals of Ouagadougou (Burkina Faso): Yalgado Ouedraogo university Hospital and Charles De Gaulle academic-pediatric Hospital. Ouagadougou is the capital and the largest town of Burkina Faso. It had about 1,500,000 inhabitants during this study.

Data for this study were extracted from the medical records of the medical emergency services of the two University Hospitals of Ouagadougou. All medical records of patients admitted in these services from July 1, 2006 to June 30, 2007 were included. Data were analysed using Epi info software version 3.3 (from CDC, Atlanta, USA).

\section{Results}

Poisoned-patients' profile and circumstances of intoxication

Out of 22720 patients admitted to the medical emergency services of the two University Hospitals, $436(1.9 \%)$ patients were admitted for acute 
poisoning. This frequency was respectively $2.34 \%$ (315/13435) and 1.30\% (121/9285) for Yalgado Ouedraogo University Hospital and Charles De Gaulle academic-pediatric Hospital. The records showed that about $50 \%$ of the patients were from 14-48 years old, about $5 \%$ were more than 48 years old and about $45.0 \%$ were less than 14 years old (table 1). Taken together, we noticed that most poisonedpatients were female (54.6\%). Among all these cases of acute intoxications, the intoxication circumstances were mentioned in only 336 medical records. Accidental poisoning, intentional self-poisoning and criminal poisoning respectively represented $70.8 \%$, $28.9 \%$ and $0.3 \%$ of acute intoxications cases.

Table 1: Distribution of poisoned-patients admitted to the emergency services of the two University hospitals of Ouagadougou (Burkina Faso) based on age, from July 1, 2006 to June 30, 2007.

\begin{tabular}{lll}
\hline Age bracket & $\begin{array}{l}\text { Number } \\
\text { of cases }\end{array}$ & $\mathbf{\%}$ \\
\hline $0-6$ & 112 & 33.1 \\
$7-13$ & 30 & 8.9 \\
$14-20$ & 43 & 12.7 \\
$21-27$ & 59 & 17.5 \\
$28-34$ & 23 & 6.8 \\
$35-41$ & 26 & 7.7 \\
$42-48$ & 18 & 5.3 \\
$>48$ & 17 & 5.0 \\
Total & 338 & 100 \\
Non-mentioned age in & 98 & 22.5 \\
the medical records & & \\
\hline
\end{tabular}

\section{Alleged substances}

In our study, the causes of intoxications were mentioned in 413 medical records among 436. Pharmaceuticals, chemicals, animals' toxins, contaminated food, alcohol and addictive drugs were the main groups of incriminated poisons in the acute intoxications.

Out of 413 poisoned-patients, 172 (41.6\%) might have been intoxicated by pharmaceuticals (figure 1). Chemicals were alleged in $26.6 \%$ cases of acute intoxications. Intoxications by animals' toxins were reported in $14.5 \%$ cases of acute intoxications. Among patients admitted to the emergency services for acute intoxication, $12.1 \%$ alleged that they ingested doubtful food. Medical records reported that $2.9 \%$ of acute poisoned-patients admitted to the medical emergency services drank alcohol. Among acute poisoned-patients, $1 \%$ was suspected to be on addictive drugs.

Admitted to the two University Hospitals of Ouagadougou (Burkina Faso); from July 1, 2006 to June 30, 2007. Other pharmaceuticals: antispasmodic, cardiotonic, antihypertensive, antidiabetic, antiemetic, antibiotic and contraceptive drugs.

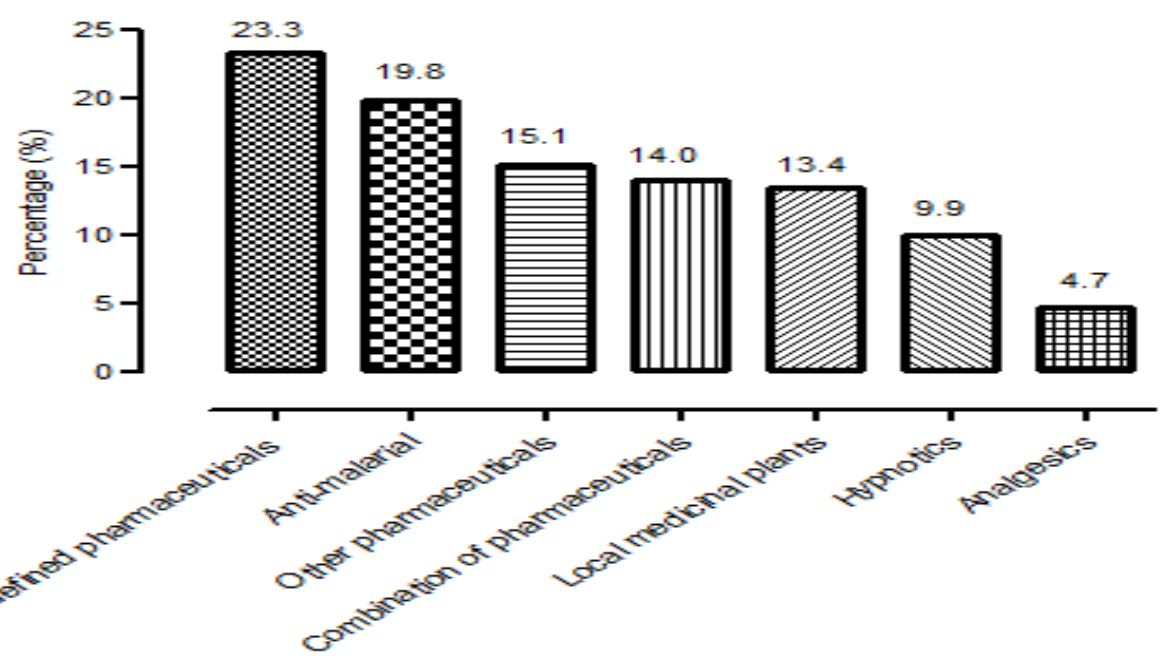

Figure 1: Percentages of different causes of intoxications in the total number of medication intoxications $(\mathbf{n}=\mathbf{1 7 2})$ Admitted to the two University Hospitals of Ouagadougou (Burkina Faso); from July 1, 2006 to June 30, 2007. Other pharmaceuticals: antispasmodic, cardiotonic, antihypertensive, antidiabetic, antiemetic, antibiotic and contraceptive drugs 


\section{Discussion}

The proportion of acute intoxications $(1.9 \%)$ in the emergency services of the two hospitals was higher than the one of Spain emergency services $(0.66 \%)$ in $2000 .{ }^{7}$ However, our results are less than those of the emergency ward of Copenhagen University Hospital in 2001 (6\%). ${ }^{8}$

As shown in table 1, pre-school children (0-6 years) followed by young adults (21-27 years) were the age groups which were frequently admitted to emergency services of Ouagadougou due to acute intoxications. It is similar to a Zimbabwean study where most cases of acute intoxications occurred among the young who were between 0 and 25 years old. ${ }^{6}$ In Finland, children below the age of 6 years were also more affected by acute intoxications than their elders. ${ }^{9}$ When analyzing SINITOX records on poisoning in Brazil from 1993 to 1996, Bortolleto $\&$ Bochner ${ }^{10}$, also found that the proportional poisoning rates were higher in the 20-29-year age bracket (18.6\%). According to other authors, these percentages can be explained by difficulties in accessing the work market and also by personal or family problems. ${ }^{11}$ The high percentage of acute intoxication in childhood may be related to the natural tendency of children to explore their environment and put whatever they find in their mouths. ${ }^{12}$ We found that females were predominant among poisoned-patients. This female predominance among acute poisoned-patients was reported in Zimbabwean $^{6}$, Greek ${ }^{13}$, Turkish ${ }^{14}$, and Iranian studies $^{15}$.

Most admissions in the emergency services of the two University Hospitals due to acute intoxications resulted from accidental poisoning. Accidental poisoning was also predominant $(>60 \%)$ among acute intoxications in Zimbabwe emergency services. ${ }^{6}$ However, in non-African countries like $\operatorname{Iran}^{15}$ and Turkey ${ }^{16}$, intentional poisoning was the most common circumstance of intoxication.

Pharmaceuticals were the leading causes of poisoning (41.6\%) followed by chemicals $(26.6 \%)$, animals' toxins (14.5\%), contaminated food (12.1\%), alcohol $(2.9 \%)$ and addictive drugs (1\%). Studies revealed that pharmaceuticals were also the most common cause of acute intoxications in Mashhad/ Iran (61.4\%) and in Zagreb/Croatia (48\%)..$^{15,17}$ This situation is not surprising in developing or emerging countries where illicit pharmaceuticals are easily obtained on the markets. ${ }^{18}$ This frequency may be associated with a lack of information and awareness and to abusive advertising by the pharmaceutical industry. ${ }^{19-20}$

Among pharmaceuticals, anti-malarial drugs (figure 1) were the most common cause of intoxication $(19.8 \%)$, followed by local medicinal plants $(13.4 \%)$. However, in most cases of pharmaceuticals poisoning $(23.3 \%)$, the class or the name of the incriminated pharmaceutical was not mentioned in the medical records. Such pharmaceuticals poisoning pattern is scarce. For example, in Iran ${ }^{15}$, central nervous system drugs were the most common drugs group while analgesic drugs were the most common in Turkey. ${ }^{14}$ As for our study, a possible justification is that anti-malarial drugs are easily accessible in Burkina Faso. Moreover, local medicinal plants are used by the majority of the population to treat diseases.

Concerning food poisonings, they were all provoked by ingestion of edible foods. They might be bacterial or viral food poisoning.

\section{Conclusion}

Pharmaceuticals were the most common cause of acute intoxication, followed by chemicals, animals' toxins, food, alcohol and addictive drugs. The great majority of poisoned-patients were young. Most admissions in the emergency services due to acute intoxications resulted from accidental poisoning.

\section{References}

1. Hodgson E, Levi PE. A text book of modern toxicology. $2^{\text {nd }}$ ed. Stamford: Appleton \& Lange; 1997. 161-2.

2. Ly AK, Timite-Konan AM, Yebouet BY, EhuaAmangoua ES, Camara-Coulibaly R, Asse Kouadio $\mathrm{V}$ et al. Acute poisoning in pediatrics at the CHU of Yopougon, Côte d'Ivoire. Bull Soc Pathol Exot 1999; 92(2):114-7.

3. Sylla M, Coulibaly Y, Dicko FT, Kourouma N, Togo B, Keita M. Intoxication aiguë accidentelle chez l'enfant au service de Pédiatrie de l'hôpital Gabriel Touré. Mali Médical 2006; 21(2):50-3.

4. Ake Assi MH, Timite-Konan AM, Ly AK, EhuaAmangoua ES, Coulibaly RF. Aspects epidemiologiques des intoxications aiguës chez l'enfant en pédiatrie à Abidjan. Médecine d'Afrique Noire 2001; 48 (11):457-60.

5. Adejuyigbe EA, Onayade AA, Senbanjo IO, Oseni SE. Childhood poisoning at the Obafemi Awolowo University Teaching Hospital, ILe-Ife, Nigeria. Nigerian J Med 2002; 11(4):183-6. 
6. Tagwireyi D, Ball DE, Nhachi CFB. Differences and similarities in poisoning admissions between urban and rural health centers in Zimbabwe. Clin Toxicol 2006; 44(3):233 - 41.

7. Burillo-Putze G, Munne P, Duenas A, Pinillos MA, Naveiro JM, Cobo JF, Alonso J. The Clinical Toxicology Working Group, Spanish Society of Emergency Medicine (SEMESTOX). National multicentre study of acute intoxication in emergency departments of Spain. Eur J Emerg Med 2003; 10(2):101-4.

8. Gude AB, Hoegberg LC, Pedersen M, Nielsen J, Angelo HR, Christensen HR. A study of 355 consecutive acute poisoning cases admitted to an emergency ward at Copenhagen University Hospital, Bispebjerg in 2001. Ugeskr Laeger 2007; 169(19):1793- 7.

9. Lamminpa A, Riihimaki V, Vilska J. Hospitalizations due to poisonings in Finland. $J$ Clin Epidemiol 1993; 46(1):47-55.

10. Bortoletto ME, Bochner R. Drug impact on human poisoning in Brazil. Cad Saude Publica 1999; 15(4):859-69.

11. Romão MR, Vieira LJES. Tentativas de suicídio por envenenamento. Rev Bras Promoção Saúde 2004; 17:14-20.

12. Ramos CLJ, Targa MBM, Stein AT. Caseload of poisoning among children treated by the Rio Grande do Sul State Toxicology Information Center (CIT/RS), Brazil. Cad Saude Publica 2005; 21:1134-41.

13. Hatzitolios AI, Sion ML, Eleftheriadis NP, Toulis E, Efstratiadis G, Vart- zopoulos D, Ziakas AG.
Parasuicidal poisoning treated in a Greek medical ward: epidemiology and clinical experience. Hum Exp Toxicol 2001; 20:611-7.

14. Goksu S YC, Kocoglu H, Tutak A, Oner U. Characteristics of acute adult poisoning in Gaziantep, Turkey. J Toxicol, Clin Toxicol 2002; 40(7):833-37.

15. Afshari R, Majdzadeh R, Balali-Mood M. Pattern of Acute Poisonings in Mashhad, Iran 19932000. J Toxicol, Clin Toxicol 2004; 42(7):965-75.

17. Güloðlu C, Kara IH. Acute poisoning cases admitted to a university hospital emergency department in Diyarbakir, Turkey. Hum Exp Toxicol 2005; 24(2):49-54.

17. Medic MG, Merkler M, Gasparovic V. Epidemiology and management of acute intoxications in emergency department. Toxicol Lett 2006; Abstracts 164S: S161-S324.

18. Rocha CE, Barros JAC, Silva MDP. Knowledge and information concerning generic drugs in a public outpatient population in Recife, Pernambuco, Brazil. Cad Saude Publica 2007; 23:1141-50.

19. Gárate NO, Cendoya CU, Zegers CC, Fernandéz EL, Alfaro JO, Diaz MT. Exposiciones a sustancias tóxicas en el Servicio de Urgencia Infantil del Hospital Doctor Félix Bulnes Cerda. Rev Chil Pediatr 2002; 73:257-62.

20. Guibert Reyes W, Torres Miranda N. Intento suicida y funcionamiento familiar. Rev Cuba Med Gen Integr 2001; 17:452-60. 